\title{
Is global ocean sprawl a cause of jellyfish blooms?
}

Carlos M Duarte ${ }^{1 * 2}$, Kylie A Pitt ${ }^{3}$, Cathy H Lucas ${ }^{4}$, Jennifer E Purcell ${ }^{5}$, Shin-ichi Uye ${ }^{6}$, Kelly Robinson ${ }^{7}$, Lucas Brotz $z^{8}$, Mary Beth Decker ${ }^{9}$, Kelly R Sutherland ${ }^{10}$, Alenka Malej ${ }^{11}$, Laurence Madin ${ }^{12}$, Hermes Mianzan ${ }^{13}$, Josep-Maria Gili ${ }^{14}$, Verónica Fuentes ${ }^{14}$, Dacha Atienza ${ }^{14}$, Francesc Pagés ${ }^{1 \dagger}$, Denise Breitburg ${ }^{15}$, Jennafer Malek $^{15}$, William M Graham ${ }^{16}$, and Robert H Condon ${ }^{7}$

Jellyfish (Cnidaria, Scyphozoa) blooms appear to be increasing in both intensity and frequency in many coastal areas worldwide, due to multiple hypothesized anthropogenic stressors. Here, we propose that the proliferation of artificial structures - associated with (1) the exponential growth in shipping, aquaculture, and other coastal industries, and (2) coastal protection (collectively, "ocean sprawl") - provides habitat for jellyfish polyps and may be an important driver of the global increase in jellyfish blooms. However, the habitat of the benthic polyps that commonly result in coastal jellyfish blooms has remained elusive, limiting our understanding of the drivers of these blooms. Support for the hypothesized role of ocean sprawl in promoting jellyfish blooms is provided by observations and experimental evidence demonstrating that jellyfish larvae settle in large numbers on artificial structures in coastal waters and develop into dense concentrations of jellyfish-producing polyps.

Front Ecol Environ 2013; 11(2): 91-97, doi:10.1890/110246 (published online 7 Sep 2012)

M ultiple explanations have been suggested for possible drivers of the apparent increase of jellyfish blooms in many coastal waters around the globe, including the depletion of predators and competitors of jellyfish by overfishing, accidental translocations, eutrophication of coastal waters, changes in freshwater flows, human modification of coastal geomorphology, and climate change (Mills 2001; Purcell et al. 2007; Purcell 2012). Most of these explanations focus on factors that affect the performance of the pelagic phase of jellyfish; however,

\section{In a nutshell:}

- Increases in jellyfish blooms have been reported across coastal locations worldwide

- Explanations for this phenomenon have focused on factors that enhance the performance of swimming jellyfish, but the importance of the benthic polyp stage, which produces the bloom forming jellyfish, has been largely overlooked

- The increase of jellyfish polyp habitat associated with the proliferation of artificial structures in coastal zones is examined as a driver of jellyfish blooms

- Reports of jellyfish polyps on artificial substrates and experiments showing their preference for these substrates provide supporting evidence

${ }^{1}$ The Oceans Institute, University of Western Australia, Crawley, Australia (carlos.duarte@uwa.edu.au); ${ }^{2}$ Department of Global Change Research, Instituto Mediterráneo de Estudios Avanzados, Esporles, Spain; ${ }^{3}$ Australian Rivers Institute and Griffith School of Environment, Griffith University, Gold Coast, Australia; ${ }^{4}$ School of Ocean 83 Earth Science, University of Southampton, National Oceanography Centre, Southampton, UK; (continued on $p 97$ ) the life history of many jellyfish species includes an often unnoticed benthic stage - in the form of polyps - from which jellyfish are produced (Boero et al. 2008). A major obstacle in identifying the causes underlying these jellyfish blooms lies in the difficulty of locating the habitat of the polyps from which the most problematic coastal jellyfish blooms develop (Mills 2001; Boero et al. 2008). In most coastal jellyfish species with bipartite life histories, embryos develop into free-swimming planula larvae, which settle on hard substrates and metamorphose into sessile polyps (Boero et al. 2008). These polyps eventually develop into juvenile medusae, such as in box jellyfish or cubozoans, or segment asexually (ie strobilate) to release juveniles named ephyrae, as is the case in the true jellyfish or scyphozoans (Arai 1997). Jellyfish polyps are very small (a few millimeters in length; Figure 1), are inconspicuous, and typically inhabit shaded environments, often suspended underneath horizontal surfaces of rocks and shells (Pitt 2000; Holst and Jarms 2007). The small size of the polyps and the difficulty of sampling them complicates locating and measuring polyp colonies in the vast coastal, marine, and estuarine environments.

Here, we examine the hypothesis that the growing proliferation of artificial structures associated with shipping, aquaculture, and other coastal industries, as well as the number and size of shoreline stabilizing structures, provides habitat for jellyfish polyps; such structures may therefore play an important role in increasing the numbers of jellyfish blooms. Support for this hypothesis is derived from observations and experimental evidence demonstrating that jellyfish larvae settle in abundance on artificial structures in coastal waters, forming dense concentrations of polyps. 

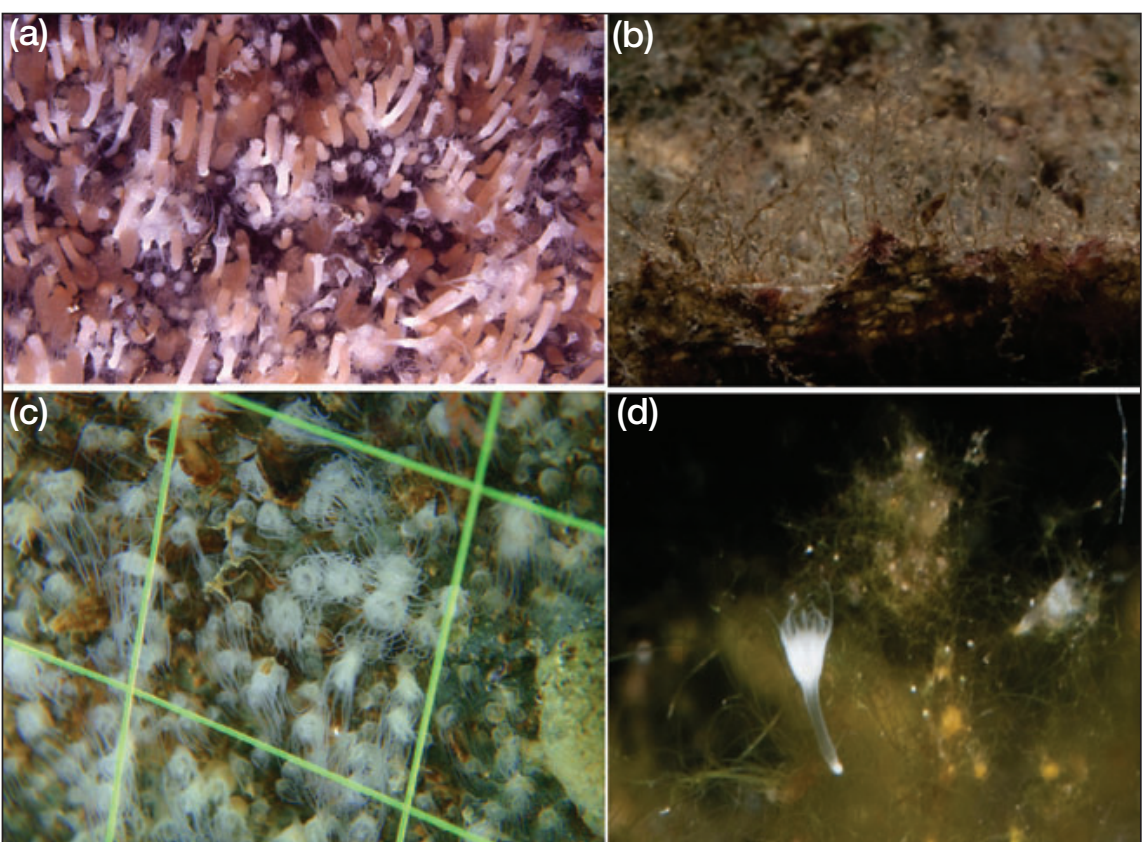

Figure 1. Photographs of jellyfish polyps attached to artificial structures. (a) Strobilating polyps of Aurelia labiata attached to a marina float in Cornet Bay, Washington State $(5 \mathrm{~cm} \times 7 \mathrm{~cm}$; from Purcell et al. 2009); (b) hydroids of Obelia dichotoma attached to plastic debris in the Ebro Delta, Spanish Mediterranean; (c) polyps of Aurelia aurita attached to a floating pier in the Inland Sea of Japan $(2.3 \mathrm{~cm} \times 3 \mathrm{~cm})$; and (d) polyp of Cotylorhiza tuberculata attached to sunken piers in abandoned aquaculture concessions in the Mar Menor, Spanish Mediterranean.

Observations of the presence of jellyfish polyps on artificial substrates were derived from surveys conducted by the authors across many locations and habitats, involving hundreds of SCUBA diving hours, and complemented by the earlier findings of others (Tables 1 and 2; WebPanel 1).
Polyps were generally located by both visual and photographic surveys, carried out by divers (Table 1; Figure 1 ). Where species identification was not possible for the polyp stage, the polyp aggregations were collected and reared in the laboratory until liberated ephyrae grew to young medusae that could be readily identified.

Two experiments - one involving Chrysaora quinquecirrha in Chesapeake Bay and the other consisting of Cotylorhiza tuberculata in the Mediterranean Sea - were conducted to assess the settlement preferences of jellyfish planulae. The Chesapeake Bay experiments with $\mathrm{C}$ quinquecirrha were conducted during summer 2010, in Mackall Cove (St Leonard, Maryland), a sub-estuary of Chesapeake Bay where $\mathrm{C}$ quinquecirrha is abundant. This experiment was designed to assess larval settlement onto oyster shells, flagstones, aged copper azole pressuretreated wood, and steel substrates, representing some of the potential natural and artificial substrates available in the Chesapeake. Recruitment panels (12.7 $\mathrm{cm} \times 10.1 \mathrm{~cm})$ were constructed by gluing the test substrates onto PVC plates that were deployed with the settlement surfaces facing downward. The panels were deployed for 39 days at approximately $0.5 \mathrm{~m}$ below the water's surface, in a randomized block design. Each experimental

Table 1. Survey observations of jellyfish polyps associated with artificial structures

\begin{tabular}{|c|c|c|c|}
\hline Species & Life form & Location & Structure \\
\hline Aurelia aurita & Polyp & Inland Sea of Japan (Japan) & $\begin{array}{l}\text { Underside of floating docks and buoys } \\
\text { and on pier pylons }\end{array}$ \\
\hline A aurita & Polyp & Southampton Water (UK) & Undersides of floating pontoons \\
\hline A aurita & Polyp & Horsea Lake (UK) & $\begin{array}{l}\text { Undersides of artificial reef structures placed } \\
\text { on the lake bottom }\end{array}$ \\
\hline A aurita & Polyp & Mar Menor (Spain) & $\begin{array}{l}\text { Polyps attached to wood pilings of tourist docks; } \\
\text { recurrent winter blooms of medusae }\end{array}$ \\
\hline Aurelia sp & Polyp and ephyra & $\begin{array}{l}\text { Koper harbor in the Gulf of } \\
\text { Trieste, Adriatic Sea (Slovenia) }\end{array}$ & Underside of oyster shells attached to piers \\
\hline $\begin{array}{l}\text { Cotylorhiza } \\
\text { tuberculata }\end{array}$ & Polyp & Mar Menor (Spain) & $\begin{array}{l}\text { Polyps attached to oyster shells and piers in } \\
\text { abandoned aquaculture concessions; also inside } \\
\text { plastic bottles found on the bottom; recurrent } \\
\text { medusae blooms }\end{array}$ \\
\hline Obelia dichotoma & Hydroid and medusa & Ebro Delta (Spain) & $\begin{array}{l}\text { Fouling organisms on the plastic objects } \\
\text { attached to the docks; medusae } \\
\text { predominant in the plankton }\end{array}$ \\
\hline
\end{tabular}


block contained one randomly ordered replicate of each substrate completely exposed to predators and a second replicate spaced approximately $2.5 \mathrm{~cm}$ from the first to exclude large predators that might be in crevices created by shoreline reinforcement structures. At the end of the experiment, the panels were placed in 7\% acid Lugol solution, polyps were counted, and the total exposed surface area of each substrate was calculated by image analysis. We used a randomized block analysis of variance (ANOVA; PROC MIXED, SAS version 9.1) to test for effects of substrate type, exposure, and the substrate $\times$ exposure interaction on the number of polyps per square centimeter on the panels. Data were rank transformed because of extreme heterogeneity of variances.

The laboratory experiment on settlement preferences of $\mathrm{C}$ tuberculata planulae tested 16 types of substrates, both natural (sand, mud, shells, wood, rocks, plants) and artificial (bricks, ropes, cans, wood, concrete, plastic, glass). Each substrate had a surface area of $150 \mathrm{~cm}^{2}$. Different substrates were placed with the settlement surfaces facing downward into 12-liter aquaria (three replicates) and planulae (19 $250 \pm$ 1350 [mean \pm standard error]) were added to each aquarium after one week. Parallel experiments were conducted in the presence and absence of light. Salinity (44-46 parts per thousand) and temperature $\left(21-23.5^{\circ} \mathrm{C}\right)$ conditions maintained in the laboratory were similar to those in the Mar Menor lagoon (Murcia, Spanish Mediterranean), where the medusae were collected. Planulae were allowed to settle for 10 days; the resulting polyps were then counted in five areas of $10 \mathrm{~cm}^{2}$ for each substrate type in each aquarium.

\section{Presence of jellyfish polyps on artificial substrates}

The surveys (Table 1) represent more than 2000 hours of diving over two decades in search of jellyfish polyps (data on surveys reported in WebPanel 1). Polyps were found across a range of artificial substrates off the coasts of Japan and the UK, as well as in the Mediterranean Sea (Table 1). The polyps were primarily located on the undersides of artificial structures in densities typically exceeding 10000 individuals per square meter and up to 100000 individuals per square meter, attached either directly to the artificial substrates or indirectly to oyster shells and tunicates on these substrates (WebPanel 1). Polyps were also observed as attached to vertical surfaces of artificial structures that had polyp colonies on the undersides, although densities were generally lower on the vertical surfaces than on the downward-facing surfaces. In some areas, years of surveys in search for polyps yielded no records of presence, but polyps were subsequently detected only when a new artificial structure was deployed in the surveyed area (WebPanel 1). Polyps were found in high densities on artificial substrates in harbors, suggesting they could be the site of massive potential releases of ephyrae (eg in excess of $1 \times 10^{10}$ year $^{-1}$, calculated in the Port of Koper, Gulf of Trieste, Slovenia; WebPanel 1). Our surveys (Table 1) and accumulated published reports (Table 2) demonstrate the widespread use of artificial structures in coastal waters by species that produce jellyfish blooms. These species include both native and non-native jellyfish, such as native Aurelia spp, one of the most widespread blooming species of jellyfish, and the exotic invasive cubomedusa Carybdea marsupialis (Tables 1 and 2), the proliferation of which near tourist areas in the Mediterranean, where artificial structures abound, is of particular concern.

\section{Experimental evidence of preference for artificial surfaces among jellyfish larvae}

Experimental evidence that jellyfish larvae prefer to settle on artificial substrates has been reported for several jellyfish species (Holst and Jarms 2007; Hoover and Purcell 2009). Our experimental assessment of substrate preferences for settlement by $\mathrm{C}$ tuberculata planulae in the Mediterranean and $\mathrm{C}$ quinquecirrha planulae in Chesapeake Bay expands on these findings by revealing significant differences in settlement preferences across substrates (ANOVA, 
Table 2. Summary of published reports of jellyfish life forms associated with artificial structures

\begin{tabular}{|c|c|c|c|c|}
\hline Species & Life form & Location & Structure & Reference \\
\hline $\begin{array}{l}\text { Aurelia } \\
\text { aurita }\end{array}$ & Polyp & $\begin{array}{l}\text { Coastal lagoon, Tapong Bay } \\
\text { (Taiwan) }\end{array}$ & Polyps attached to oyster cultures & Lo et al. (2008) \\
\hline A aurita & Polyp & Wakasa Bay (Japan) & Underside of floating docks & Matsumura et al. (2005) \\
\hline A aurita & Polyp & Tokyo Bay (Japan) & $\begin{array}{l}\text { On pylon in bottom hypoxic layer } \\
\text { where other sessile organisms are } \\
\text { absent }\end{array}$ & $\begin{array}{l}\text { Ishii et al. (2008); Ishii and } \\
\text { Katsukoshi (2010) }\end{array}$ \\
\hline A aurita & Polyp & Kagoshima Bay (Japan) & Underside of floating piers and buoys & Miyake et al. (2002) \\
\hline A aurita & Polyp & $\begin{array}{l}\text { Murotsu fishing port, } \\
\text { Yamaguchi (Japan) }\end{array}$ & $\begin{array}{l}\text { Underside of floating piers; cellophane } \\
\text { cover of cigarette packaging }\end{array}$ & Miyake et al. (2002) \\
\hline A aurita & Polyp & $\begin{array}{l}\text { Conero Promontory, Ancona, } \\
\text { Adriatic Sea (Italy) }\end{array}$ & Iron shipwreck & Di Camillo et al. (2010) \\
\hline A aurita & $\begin{array}{l}\text { Polyp and } \\
\text { ephyra }\end{array}$ & Bahía Blanca estuary (Argentina) & Maximum abundances close to harbors & Mianzan (I989) \\
\hline A aurita & Polyp & North Pacific coast (US) & Undersides of floating docks in marinas & $\begin{array}{l}\text { Kozloff (1983) } \\
\text { (cited in Purcell et al. } \\
\text { 2009) }\end{array}$ \\
\hline A labiata & Polyp & $\begin{array}{l}\text { Cornet Bay Marina, Washington } \\
\text { (US) }\end{array}$ & Underside of marina floats & Purcell et al. (2009) \\
\hline Aurelia spp & Polyp & Tasmania (Australia) & $\begin{array}{l}\text { Undersides of breakwaters and } \\
\text { floating docks }\end{array}$ & Willcox et al. (2008) \\
\hline $\begin{array}{l}\text { Carybdea } \\
\text { marsupialis }\end{array}$ & Medusa & Denia,Valencia (Spain) & $\begin{array}{l}\text { Newly released medusae only appear } \\
\text { where breakwaters are installed }\end{array}$ & $\begin{array}{l}\text { Bordehore et al. } \\
\text { (20II) }\end{array}$ \\
\hline $\begin{array}{l}\text { Chrysaora } \\
\text { lactea }\end{array}$ & $\begin{array}{l}\text { Polyp and } \\
\text { ephyra }\end{array}$ & Bahía Blanca estuary (Argentina) & Maximum abundances close to harbors & Mianzan (1989) \\
\hline $\begin{array}{l}\text { Chrysaora } \\
\text { quinquecirrha }\end{array}$ & Medusa & Chesapeake Bay (US) & Wild and cultured oyster shells & Cargo and Schultz (1966) \\
\hline $\begin{array}{l}\text { Cotylorhiza } \\
\text { tuberculata }\end{array}$ & Polyp & $\begin{array}{l}\text { lonian island of Lefkada } \\
\text { (Greece) }\end{array}$ & Polyps attached to glass debris & Kikinger (1992) \\
\hline $\begin{array}{l}\text { Cyanea } \\
\text { capillata }\end{array}$ & Polyp & $\begin{array}{l}\text { Port Phillip Bay, Victoria } \\
\text { (Australia) }\end{array}$ & Pier & $\begin{array}{l}\text { Johnston and Keough } \\
(2000)\end{array}$ \\
\hline $\begin{array}{l}\text { Ectopleura } \\
\text { larynx }\end{array}$ & $\begin{array}{l}\text { Hydroid and } \\
\text { medusoid }\end{array}$ & Fish farms (Norway) & $\begin{array}{l}\text { Predominant fouling organism } \\
\text { collapsing fish-pen nets }\end{array}$ & Guenther et al. (2010) \\
\hline E larynx & $\begin{array}{l}\text { Hydroid and } \\
\text { medusoid }\end{array}$ & German Bight (Germany) & $\begin{array}{l}\text { Offshore wind farm platform (fully } \\
\text { covered } 2 \text { weeks after deployment) }\end{array}$ & Schroeder et al. (2006) \\
\hline $\begin{array}{l}\text { Filter feeders, } \\
\text { including } \\
\text { hydroids }\end{array}$ & Polyp & California (US) & Riprap & Pister (2009) \\
\hline $\begin{array}{l}\text { General } \\
\text { "hydroids" }\end{array}$ & Polyp & Worldwide & Plastic floating debris & Barnes (2002) \\
\hline $\begin{array}{l}\text { Obelia spp; } \\
\text { Aurelia }\end{array}$ & $\begin{array}{l}\text { Hydroid and } \\
\text { polyp }\end{array}$ & $\begin{array}{l}\text { Puget Sound, Washington (US); } \\
\text { also in San Francisco Bay (US) }\end{array}$ & $\begin{array}{l}\text { Underside of floats;"sheets of Aurelia } \\
\text { scyphistoma" in some locations }\end{array}$ & $\begin{array}{l}\text { Kozloff (1983) } \\
\text { (cited in Purcell et al. } \\
\text { 2009) }\end{array}$ \\
\hline $\begin{array}{l}\text { Rhizostoma } \\
\text { pulmo }\end{array}$ & $\begin{array}{l}\text { Polyp and } \\
\text { ephyra }\end{array}$ & Northeastern Spain & $\begin{array}{l}\text { Polyps on concrete columns; ephyrae } \\
\text { in plankton samples collected nearby }\end{array}$ & Fuentes et al. (201 I) \\
\hline
\end{tabular}




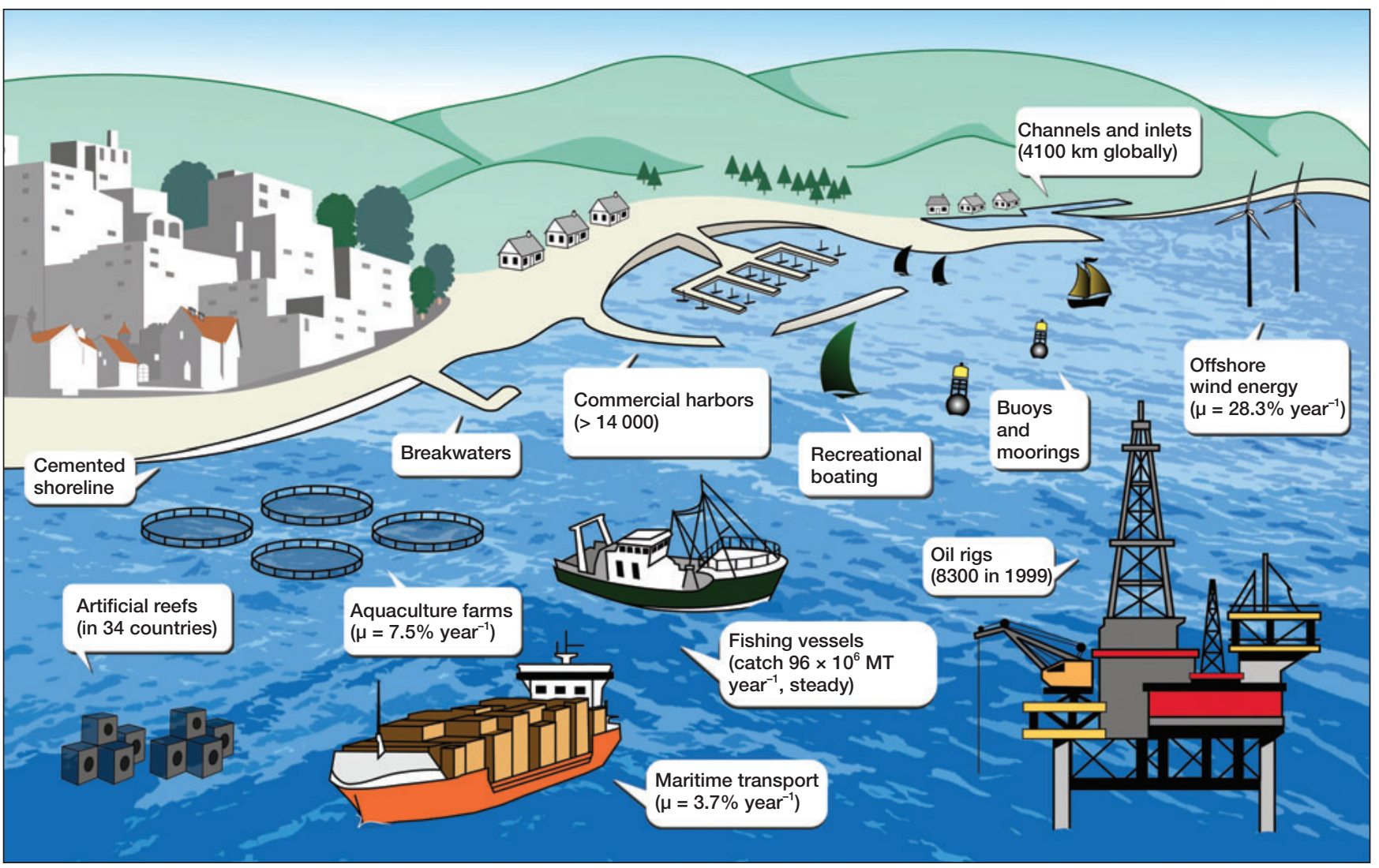

Figure 3. A representation of activities responsible for global ocean sprawl. Data sources - aquaculture production/growth and fisheries catch: FAO Fishstats (www.fao.org/fishery/statistics/software/fishstat); commercial harbors: the Ship Atlas (www.portinfo.co.uk); merchant fleet growth: Maritime Knowledge Center (www.imo.org/KnowledgeCentre, growth from 1990 to 2008); offshore wind energy: Global Wind Energy Outlook (www.gwec.net, growth expected from 2013 to 2020); length of channels and inlets: Waltham and Connolly (2011). MT = metric tons; $\mu=$ annual growth rate.

$P<0.0001$; WebTable 1) and that recruitment of polyps on artificial substrates was comparable to or higher than that on natural substrates (Figure 2), particularly when the panels were spaced closely together, to exclude large predators, or else placed in the dark.

The evidence summarized here shows that jellyfish planulae preferentially settle on artificial substrates, which are often used as settlement plates to collect jellyfish polyps (Purcell et al. 2007). Consistent with these results, field surveys revealed the presence of jellyfish polyps on many artificial substrates. Potentially suitable artificial structures include submarine pillars, platforms and walls in harbors and piers, floating docks, oil rigs, aquaculture structures, platforms supporting coastal wind turbines, riprap, bridges, buoys, moorings, artificial urban waterways, ship hulls, artificial reefs, breakwaters, and garbage (Tables 1 and 2). The construction of artificial structures in coastal areas is growing at rates ranging from 3.7\% year $^{-1}$ (merchant ships requiring harbor space) to $28.3 \%$ year $^{-1}$ (offshore wind energy), contributing to the increasing extent of global ocean sprawl (Figure 3).

The global ocean sprawl of artificial substrates suitable for jellyfish polyps is likely to be particularly critical in benthic regions with predominantly soft sediments (eg the Gulf of Mexico, the southeast coast of South America, and the Yellow and East China seas), where natural hard substrates are scarce. Transport by hull fouling of ships or on oil platforms being located or relocated at sea provides mechanisms for invasive jellyfish translocations (Graham and Bayha 2007), with docks and harbor walls providing new dispersal centers for the invaders. The spatial arrangement of artificial structures may reduce distances between suitable settlement sites for larvae and thus act as "stepping stones" that facilitate range expansions and invasive processes, consequently increasing the spatial extent of blooms. The proliferation of these structures may compensate - or even overcompensate - for the disappearance of natural habitat, such as the decline in eastern oyster (Crassostrea virginica; Breitburg and Fulford 2006) abundance in Chesapeake Bay, the primary natural substrate for polyps of $C$ quinquecirrha (Cargo and Schultz 1966). With nearly $2000 \mathrm{~km}$ of riprap, bulkhead, and other shoreline reinforcement structures, and more than 25000 docks in the tidal waters of the Maryland portion of the bay, the proliferation of hard substrate in Chesapeake Bay and its tributaries has greatly expanded habitat suitable for $\mathrm{C}$ quinquecirrha polyps and in some areas may offset the decline in oyster populations.

Artificial structures provide ideal conditions for settlement by jellyfish polyps. Floating docks and crevices 
within riprap increase the amount of shaded surfaces of the type that polyps prefer (Pitt 2000; Holst and Jarms 2007). Sea walls and marinas provide shelter in areas that would otherwise be exposed to high wave energy, thereby protecting polyps from being scoured from the surfaces to which they are attached. The rapid colonization and strobilation capacities of polyps (Pitt 2000) enable them to cope with the continuous replacement and maintenance of artificial substrates; at the same time, these disturbances remove the predators and competitors that inhabit similar areas (eg barnacles, sponges, bryozoans, ascidians). Trash materials, which also provide suitable substrates for polyps (eg plastic bags; Tables 1 and 2), collect around artificial structures in harbors (Bulleri and Chapman 2010) and possibly in oceanic areas, as denoted by high densities of suspended plastic materials (Derraik 2002). Ports are often associated with high fishing pressure and turbidity, as well as elevated levels of nutrients, organic matter, and pollutants, thus potentially enhancing polyp food supply and excluding predators and competitors, all of which favors polyp survival and proliferation. Many of these environments have hypoxic bottom waters, to which jellyfish polyps are particularly resistant (Breitburg et al. 1997; Purcell et al. 2001; Vaquer-Sunyer and Duarte 2008).

Individual polyps multiply asexually through the production of buds and stolons, longitudinal fission, or the formation of podocysts, which are dormant and potentially resistant to stressful conditions such as low food supply and hypoxia (Arai 2009). Juvenile scyphozoan and hydrozoan medusae are produced asexually from the polyps, which can produce as many as 40 ephyrae during each strobilation event (Lucas 2001). Moreover, polyps of many jellyfish species can strobilate repeatedly, are perennial, and can produce new polyps and medusae for years (Arai 1997). Consequently, every new polyp potentially produces hundreds or even thousands of medusae, which then produce thousands or millions of planulae (Boero et al. 2008). Medusae are often reported to be abundant in harbors, where artificial substrates abound (Table 1; WebPanel 1; Lotan et al. 1994; Purcell 2012); indeed, medusa densities have been shown to decline when artificial substrate is removed (Lo et al. 2008). Thus, as asexual production by polyps is believed to be a key driver of medusae outbreaks in coastal areas, artificial structures may be acting as nurseries, facilitating jellyfish blooms in adjacent waters.

The increase in frequency of proliferations of the giant jellyfish Nemopilema nomurai (up to $2 \mathrm{~m}$ in diameter) in East Asian seas arguably represents the most dramatic case of increased jellyfish blooms; this species has caused substantial losses to regional fisheries and has alarmed the public (Kawahara et al. 2006). The habitat for polyps of most problematic jellyfish species, such as $N$ nomurai, is still largely unknown; however, the distribution of these jellyfish includes the coasts of the Korean Peninsula, China, and Japan (Kawahara et al. 2006), which is perhaps the region of the world experiencing the fastest growth in aquaculture and shipping activities (Duarte et al. 2009) and their associated infrastructures (Purcell et al. 2007; Uye 2008). Moreover, the polyps of some jellyfish can attach to and develop on macroalgae, suggesting that the exponential growth of macroalgal aquaculture in China (Duarte et al. 2009) may greatly increase the available natural substrate for polyps. Indeed, the expansion of aquaculture along the coast of China may have provided considerable amounts of new habitat for jellyfish polyps in the East China and South China seas (Dong et al. 2010).

The expansion of artificial structures in coastal zones increases the probability of planulae encountering suitable settlement habitats, and may explain why coastal jellyfish blooms appear to be more prevalent now than in the past in some areas (Mills 2001; Purcell et al. 2007). This hypothesis applies only to jellyfish species with benthic stages and is not applicable to all bloom-forming jellyfish. Unfortunately, demonstrating a direct relationship between ocean sprawl and jellyfish proliferation is precluded by the impracticality of conducting experiments at the appropriate required spatial and temporal scales. Yet, the potential for artificial substrates to serve as a substrate for polyps conducive to jellyfish blooms must be considered in coastal planning. Increased awareness of the possible link between ocean sprawl and jellyfish proliferation should prompt coastal managers to (1) change the design and surface characteristics of artificial structures deployed in the coastal zone, (2) manage associated environmental conditions to reduce those favoring jellyfish polyps (which include high turbidity, high nutrient and organic loads, and hypoxia, often experienced in harbors and other heavily altered environments), and (3) regulate garbage disposal so as to avoid introduction of substrates, such as plastic materials, that can also support jellyfish polyps.

\section{Acknowledgements}

This research is a contribution to the Global Expansion of Jellyfish Blooms: Magnitude, Causes and Consequences Working Group, supported by the National Center for Ecological Analysis and Synthesis (NCEAS is supported by the National Science Foundation [grant \#DEB-9421535], the University of California at Santa Barbara, and the State of California) and the Evaluation of Ecosystem Impacts of Global Change in Mediterranean Ecosystems (MEDEICG) project, funded by the Spanish National Plan of I+D (CTM2009-07013). The C quinquecirrha experiments were conducted by DB and JM and supported by National Oceanic and Atmospheric Administration grant \#NA09NOS4780214 to DB. We thank K Davies for artistic work.

\section{References}

Arai MN. 1997. A functional biology of Scyphozoa. London, UK: Chapman \& Hall.

Arai MN. 2009. The potential importance of podocysts to the formation of scyphozoan blooms: a review. Hydrobiologia 616: 241-46.

Barnes DKA. 2002. Biodiversity: invasions by marine life on plastic debris. Nature 416: 808-09. 
Boero F, Bouillon J, Gravili C, et al. 2008. Gelatinous plankton: irregularities rule the world (sometimes). Mar Ecol-Prog Ser 356: 299-310.

Bordehore C, Fuentes VL, Atienza D, et al. 2011. Detection of an unusual presence of the cubozoan Carybdea marsupialis at shallow beaches located near Denia, Spain (south-western Mediterranean). Mar Biodivers Rec 4: e69; doi:10.1017/ S1755267211000650.

Breitburg DL, Loher T, Pacey CA, et al. 1997. Varying effects of low dissolved oxygen on trophic interactions in an estuarine food web. Ecol Monogr 67: 489-507.

Breitburg DL and Fulford RS. 2006. Oyster-sea nettle interdependence and altered control within the Chesapeake ecosystem. Estuar Coast 29: 776-84.

Bulleri F and Chapman MG. 2010. The introduction of coastal infrastructure as a driver of change in marine environments. $J$ Appl Ecol 47: 26-35.

Cargo DG and Schultz LP. 1966. Notes on the biology of the sea nettle, Chrysaora quinquecirrha, in Chesapeake Bay. Chesapeake Science 7: 95-100.

Derraik JGB. 2002. The pollution of the marine environment by plastic debris: a review. Mar Pollut Bull 44: 842-52.

Di Camillo C, Bettia F, Boa M, et al. 2010. Contribution to the understanding of seasonal cycle of Aurelia aurita (Cnidaria: Scyphozoa) scyphopolyps in the northern Adriatic Sea. J Mar Biol Assoc UK 90: 1105-10.

Dong Z, Liu D, and Keesing JK. 2010. Jellyfish blooms in China: dominant species, causes and consequences. Mar Pollut Bull 60: 954-63.

Duarte CM, Holmer M, Olsen Y, et al. 2009. Will the oceans help feed humanity? BioScience 59: 967-76.

Fuentes V, Straehler-Pohl I, Atienza D, et al. 2011. Life cycle of the jellyfish Rhizostoma pulmo (Scyphozoa: Rhizostomeae) and its distribution, seasonality and inter-annual variability along the Catalan coast and the Mar Menor (Spain, NW Mediterranean). Mar Biol 158: 2247-66.

Graham WM and Bayha KM. 2007. Biological invasions by marine jellyfish. In: Nentwig N (Ed). Biological invasions. Berlin, Germany: Springer-Verlag.

Guenther J, Misimi E, and Sunde LM. 2010. The development of biofouling, particularly the hydroid Ectopleura larynx, on commercial salmon cage nets in Mid-Norway. Aquaculture 300: 120-27.

Holst $S$ and Jarms G. 2007. Substrate choice and settlement preferences of planula larvae of five Scyphozoa (Cnidaria) from German Bight, North Sea. Mar Biol 151: 863-71.

Hoover RA and Purcell JE. 2009. Substrate preferences of scyphozoan Aurelia labiata polyps among common dock-building materials. Hydrobiologia 616: 259-67.

Ishii H, Ohba T, and Kobayashi T. 2008. Effects of low dissolved oxygen on planula settlement, polyp growth and asexual reproduction of Aurelia aurita. Plankton Benthos Res 3: 107-13.

Ishii $\mathrm{H}$ and Katsukoshi K. 2010. Seasonal and vertical distribution of Aurelia aurita polyps on a pylon in the innermost part of Tokyo Bay. J Oceanogr 66: 329-36.

Johnston EL and Keough MJ. 2000. Field assessment of effects of timing and frequency of copper pulses on settlement of sessile marine invertebrates. Mar Biol 137: 1017-29.

Kawahara M, Uye S-I, Ohtsu K, and Iizumi H. 2006. Unusual population explosion of the giant jellyfish Nemopilema nomurai (Scyphozoa: Rhizostomeae) in East Asian waters. Mar EcolProg Ser 307: 161-73.

Kikinger R. 1992. Cotylorhiza tuberculata (Cnidaria: Scyphosoa) life history of a stationary population. Mar Ecol 13: 333-62.

Kozloff EN. 1983. Seashore life of the northern Pacific coast. Seattle, WA: University of Washington Press.

Lo W, Purcell JE, Hung J, et al. 2008. Enhancement of jellyfish (Aurelia aurita) populations by extensive aquaculture rafts in a coastal lagoon in Taiwan. ICES J Mar Sci 65: 453-61.

Lotan A, Fine M, and Ben-Hillel R. 1994. Synchronization of the life cycle and dispersal pattern of the tropical invader scyphomedusan Rhopilema nomadica is temperature dependent. Mar Ecol-Prog Ser 109: 59-65.
Lucas CH. 2001. Reproduction and life history strategies of the common jellyfish, Aurelia aurita, in relation to its ambient environment. Hydrobiologia 451: 229-46.

Matsumura K, Kamiya K, Yamashita K, et al. 2005. Genetic polymorphism of the adult medusae invading an electric power station and wild polyps of Aurelia aurita in Wakasa Bay, Japan. J Mar Biol Assoc UK 85: 563-68.

Mianzan H. 1989. Scyphomedusae de la Bahía Blanca. Boletim do Instituto Oceanogràfico de Sao Paulo 37: 29-32.

Mills CE. 2001. Jellyfish blooms: are populations increasing globally in response to changing ocean conditions? Hydrobiologia 451: 55-68.

Miyake H, Terazaki M, and Kakinuma Y. 2002. On the polyps of the common jellyfish Aurelia aurita in Kagoshima Bay. J Oceanogr 58: 451-59.

Pister B. 2009. Urban marine ecology in southern California: the ability of riprap structures to serve as rocky intertidal habitat. Mar Biol 156: 861-73.

Pitt KA. 2000. Life history and settlement preferences of the edible jellyfish Catostylus mosaicus (Scyphozoa: Rhizostomeae). Mar Biol 136: 269-80.

Purcell JE. 2012. Jellyfish and ctenophore blooms coincide with human proliferations and environmental perturbations. Ann Rev Mar Sci 4: 209-35.

Purcell JE, Breitburg DL, Decker MB, et al. 2001. Pelagic cnidarians and ctenophores in low dissolved oxygen environments: a review. In: Rabalais NN and Turner RE (Eds). Coastal hypoxia: consequences for living resources and ecosystems. Washington, DC: American Geophysical Union.

Purcell JE, Hoover RA, and Schwarck NT. 2009. Interannual variation of strobilation by the scyphozoan Aurelia labiata in relation to polyp density, temperature, salinity, and light conditions in situ. Mar Ecol-Prog Ser 375: 139-49.

Purcell JE, Uye S-I, and Lo WT. 2007. Anthropogenic causes of jellyfish blooms and their direct consequences for humans: a review. Mar Ecol-Prog Ser 350: 153-74.

Schroeder A, Orejas C, and Joschko T. 2006. Benthos in the vicinity of the piles: FINO 1 (North Sea). In: Koller J and Koppel P (Eds). Offshore wind energy: research on environmental impacts. Berlin, Germany: Springer-Verlag.

Uye S-I. 2008. Blooms of the giant jellyfish Nemopilema nomurai: a threat to the fisheries sustainability of the East Asian Marginal Seas. Plankton Benthos Res 3: 125-31.

Vaquer-Sunyer R and Duarte CM. 2008. Thresholds of hypoxia for marine biodiversity. P Natl Acad Sci USA 105: 15452-57.

Waltham NJ and Connolly RM. 2011. Global extent and distribution of artificial, residential waterways in estuaries. Estuar Coast Shelf S 94: 192-97.

Willcox S, Moltschaniwskyj NA, and Crawford CM. 2008. Population dynamics of natural colonies of Aurelia sp scyphistomae in Tasmania, Australia. Mar Biol 154: 661-70.

${ }^{5}$ Shannon Point Marine Center, Western Washington University, Anacortes, WA; ${ }^{6}$ Graduate School of Biosphere Science, Hiroshima University, Higashi-Hiroshima, Japan; ${ }^{7}$ Dauphin Island Sea Lab, Dauphin Island, AL; ${ }^{8}$ Fisheries Centre, University of British Columbia, Vancouver, British Columbia, Canada; ${ }^{9}$ Department of Ecology and Evolutionary Biology, Yale University, New Haven, CT; ${ }^{10}$ California Institute of Technology, Pasadena, CA; ${ }^{11}$ Marine Biological Station, National Institute of Biology, Piran, Slovenia; ${ }^{12}$ Woods Hole Oceanographic Institution, Woods Hole, MA; ${ }^{13}$ CONICEPT-Instituto Nacional de Investigación y Desarrollo Pesquero, Mar del Plata, Argentina; ${ }^{14}$ Institut de Ciències del Mar, Barcelona, Spain; ${ }^{15}$ Smithsonian Environmental Research Center, Edgewater, MD; ${ }^{16}$ Department of Marine Science, University of Southern Mississippi, Stennis Space Center, MS; ${ }^{\dagger}$ (deceased) 